\title{
Age and tree spacing and their effects on energy properties of Ateleia glazioviana
}

\author{
Elder Eloy ${ }^{1}$ Dimas Agostinho da Silva ${ }^{2}$ Braulio Otomar Caron ${ }^{3}$ \\ Elvis Felipe Elli ${ }^{4}$ Felipe Schwerz $^{3}$
}

\begin{abstract}
'Departamento de Engenharia Florestal, Universidade Federal de Santa Maria (UFSM), Campus de Frederico Westphalen, 98400-000, Frederico Westphalen, RS, Brasil. E-mail: eloyelder@yahoo.com.br. Corresponding author.

${ }^{2}$ Departamento de Engenharia e Tecnologia Florestal, Universidade Federal do Paraná (UFPR), Curitiba, PR, Brasil.

${ }^{3}$ Departamento de Ciências Agronômicas e Ambientais, Universidade Federal de Santa Maria (UFSM), Campus de Frederico Westphalen, Frederico Westphalen, RS, Brasil.

${ }^{4}$ Departamento de Engenharia de Sistemas Agrícolas, Escola Superior de Agricultura “Luiz de Queiroz” (ESALQ), Universidade de São Paulo (USP), Piracicaba, SP, Brasil.
\end{abstract}

ABSTRACT: The use of wood for energy purposes is common in Brazil, motivated mainly by the diversity of species that present a potential for energy production. The objective of this study was to determine the effects of tree age and spacing on the energy properties of different components of the biomass: wood, bark, and branch of the species Ateleia glazioviana Baill, distributed at different spacings: $2.0 \times 1.0 m, 2.0 \times$ $1.5 \mathrm{~m}, 3.0 \times 1.0 \mathrm{~m}$, and $3.0 \times 1.5 \mathrm{~m}$ in the $1^{\text {st }}, 3^{\text {rd }}$, and $5^{\text {th }}$ year after the planting. The experiment was carried out in a randomized complete block design with three replications. The following variables were determined: biomass (BIO), gross calorific power (GCV), basic density (BD), energy productivity (EP), energy density (ED), fixed carbon content (FCC), volatile material content (VMC), and ash content (AC). Different tree ages significantly affected all analyzed variables, increasing the distribution of BIO, EP, AC, BD, and ED with no tendency to stabilize over time. The four tree spacings induced different levels of BIO and EP, with a trend toward lower values with increasing tree spacing for all assessed periods. The four components of the trees had a significant effect on the variables BIO, EP, GCV, FCC, VMC, and AC.

Key words: Timbó, biomass, gross calorific power, energy productivity.

\section{A idade e o espaçamento de plantio e suas influências nas} propriedades energéticas da Ateleia glazioviana

RESUMO: A utilização da madeira para fins energéticos é elevada no pais, motivada principalmente pela diversidade de espécies que apresentam potencialidade de geração de energia. Esse trabalho teve como objetivo determinar o efeito da idade e do espaçamento de plantio nas propriedades energéticas em diferentes compartimentos da biomassa: madeira, casca e galho da espécie Ateleia glazioviana Baill, distribuida em diferentes espaçamentos: 2,0x1,0m, 2,0x1,5m, 3,0x1,0m e 3,0x1,5m, no 1-, 3- e 5-ano após o plantio. O presente trabalho foi realizado em um experimento instalado em delineamento experimental de blocos completos casualizados em três repetições. Foram determinadas as variáveis biomassa (BIO), poder calorifico superior (PCS), massa específica básica (ME), produtividade energética (PE), densidade energética (DE), teor de carbono fixo (CF), teor de material volátil (MV) e teor de cinzas (CZ). Concluiu-se que as diferentes idades das árvores influenciam significativamente todas as variáveis analisadas, proporcionando uma distribuição crescente da BIO, PE, CF, ME e $D E$, sem tendência a estabilização ao longo do tempo. Os quatro espaçamentos de plantio induzem a diferentes produções de BIO e PE, com uma tendência de redução dos seus valores com o aumento do espaçamento, em todos os períodos avaliados. Os quatro compartimentos das árvores induzem a um efeito significativo das variáveis BIO, PE, PCS, CF, MV e CZ.

Palavras-chave: timbó, biomassa, poder calorifico superior, produtividade energética.

\section{INTRODUCTION}

Proper use of any material requires the knowledge of its characteristics, especially those related to its applicability. This is not different with the forest biomass, with the characterization of its properties being necessary to determine its final use. Each species presents different characteristics, and thus verification of different factors that can intrinsically affect its quality and use is recommended.

The choice of the genetic material to be used in the plantation of forest stands from both native and exotic species is extremely important for 
use as an alternative source of energy. However, for this to become feasible, it is necessary to know the essential characteristics of forest and its use, with respect to the ecological and silvicultural factors, and those related to the energy potential. These factors support the decision making for the implantation of forest stands (ELOY et al., 2015).

With the increasing demand for renewable energy sources, studies about the potential of energy generation from forest biomass have been conducted in Brazil and worldwide. Studies reported biomass capacity for clean energy production, such as the research performed by LIMA et al. (2011), VIDAURRE et al. (2012), PROTÁSIO et al. (2013), CARON et al. (2015), and ELOY et al. (2016a). However, to increase the efficiency of the conversion of wood into energy, it is necessary to use appropriate technologies to assess its true potential in carbonization, heat production, and cogeneration. In this context, the expectations about the use of forest biomass as a raw material for energy generation are promising.

In a forest production system, wood production as energy resources aim greater biomass production per unit area over a short time. In this way, together with exploration in a dense system, with the objective of producing biomass, the concept of short rotation plantations arises (CARON et al., 2015). Within this context, for Brazil to increase the participation of biomass and wood products in its energy matrix, improvements in access to forestry technologies are required for small and mediumsized producers, both for forestry management and conversion of wood to energy, increasing the generation potential of future forest plantations.

Tree spacing is one of the main factors that affect the establishment of forests, because it has silvicultural, technological, and economic implications, affecting the tree growth rate, age at cutting, wood quality, forest practices employed, and consequently production costs (LELES et al., 2011). Thus, when targeting timber production for energy purposes, denser spacing is usually recommended to produce a larger volume of biomass per unit area in the shortest possible time (ELOY, 2015).

The use of wood for energy purposes is common in Brazil, motivated mainly by the diversity of species that have the energy properties. Currently, $8.2 \%$ of the energy produced domestically comes from firewood and charcoal, according to official sources linked to the energy area (MME, 2016). Thus, it is essential to establish forest experiments in which the original conditions of site, planting, and the ages of the trees are known. This would support the generation of new information regarding the qualification of species destined for the generation of energy, and thus with the goal of establishing forest masses destined to produce wood for energy.

In this context, the present study aimed to determine the effects of planting age and spacing on energy properties of different components of the biomass of Ateleia glazioviana Baill.

\section{MATERIALS AND METHODS}

\section{Study area}

The experiment was carried out in an area belonging to the Universidade Federal de Santa Maria (UFSM), under geographic coordinates of $27^{\circ} 22^{\prime} \mathrm{S}$; $53^{\circ} 25^{\prime} \mathrm{W}$, at $480 \mathrm{~m}$ altitude, in the city of Frederico Westphalen, Rio Grande do Sul.

According to the Köppen climate classification, the climate in this region is Cfa, i.e., humid subtropical climate, with an average annual temperature of $19.1{ }^{\circ} \mathrm{C}$, varying with a maximum of $38^{\circ} \mathrm{C}$ and a minimum of $0^{\circ} \mathrm{C}$, and an average annual rainfall of $1606 \mathrm{~mm}$. The experimental area is approximately $30 \mathrm{~km}$ from Iraí, which is the city taken as reference for the climate classification data. As proposed by MALUF (2000), Iraí has an average annual temperature of $18.8^{\circ} \mathrm{C}$ and average temperature of $13.3^{\circ} \mathrm{C}$ in the coldest month.

The experiment was arranged in a randomized complete block design. It was a $3 \times 4$ $\times 3$ factorial experiment, i.e., three time periods $\left(1^{\text {st }}\right.$, $3^{\text {rd }}$, and $5^{\text {th }}$ year after planting), four tree spacings $(2.0 \times 1.0 \mathrm{~m}, 2.0 \times 1.5 \mathrm{~m}, 3.0 \times 1.0 \mathrm{~m}$, and $3.0 \times$ $1.5 \mathrm{~m}$ ), and three tree components (wood, bark, and branch) with three replicates.

The block had four experimental units, which allocated the four levels of planting spacings. Plots were divided into sub-plots for the different evaluation stages over time, and three trees were collected per evaluation period for each planting spacing. Thus, for each evaluation period, 36 trees were collected and evaluated, totaling 108 trees in all periods.

The soil of the area is classified as typical dystrophic red latosol, clayey texture, belonging to the mapping unit of Passo Fundo (EMBRAPA, 2006).

Tree sampling
Destructive assessments of the trees
were carried out during three different time 
periods: in the $1^{\text {st }}$ year (2009), $3^{\text {rd }}$ year (2011), and $5^{\text {th }}$ year (2013) after planting the experiment, and 36 trees were assessed during each period. For tree sampling, six discs approximately $2 \mathrm{~cm}$ thick were taken along the stem at the following positions: $0 \%$ (base), 1.30m (diameter at breast height - DBH), $25 \%, 50 \%, 75 \%$, and $100 \%$ of the total height of the tree, and two symmetrically opposite wedges of each disk were sectioned.

Tree samples were collected in a stratified manner, i.e., the lower, middle, and upper stratum of the tree canopy, to obtain a homogeneous material that represents the entire canopy length. These were identified and taken for drying in a circulation and renewal oven, to obtain the dry product. Samples of wood, bark, and branch were dried at $103^{\circ} \mathrm{C}$ at $0 \%$ moisture, to determine the respective humidity content.

The data for the sampled leaves were not computed, because senescence started prior to the period when the evaluations were carried out, that is, in the month of September.

\section{Characterization of the evaluated properties}

To determine the biomass (BIO), the direct method was used, which consisted of cutting and weighing of the different components of trees (SANQUETTA, 2002). Total fresh masses of the sampled trees were determined under field condition, and samples were taken from each component to obtain its moisture content in the laboratory.

Regarding the determination of the gross calorific value (GCV) and the immediate chemical analysis (ICA), samples taken from the trees were ground in a slicer with a 40-mesh sieve to obtain a thinner and more uniform material. Evaluation for GCV was performed using a digital bomb calorimeter, C5000 Cooling System model, IKA Werke, with adiabatic operating principle, according to the technical standard NBR 8633 (ABNT, 1984), and, in the case of the ICA, the technical standard NBR 8112 (ABNT, 1986) was used, from which the concentrations of volatile compounds, ash, and fixed carbon compounds were determined.

To determine the basic density (BD), the materials obtained in the sampling were used. The procedures were performed according to the technical standard NBR 11941 (ABNT, 2003). Regarding the determination of energy productivity (EP), the BIO values with their respective GCV were multiplied according to the following equation:

$\mathrm{EP}=\mathrm{BIO} \times \mathrm{GCV}$ where: $\mathrm{EP}=$ Energy productivity $\left(\mathrm{Gcal} \mathrm{ha}^{-1}\right)$; $\mathrm{BIO}=$ Dry biomass of each component $\left(\right.$ ton $\left.\mathrm{ha}^{-1}\right)$, and $\mathrm{GCV}=$ Gross calorific value $\left(\mathrm{kcal} \mathrm{kg}^{-1}\right)$.

To determine the energy density (ED), BD and GCV values were multiplied according to the following equation:

$\mathrm{ED}=\mathrm{BD} \times \mathrm{GCV}$

where: $\mathrm{ED}=$ Energy density $\left(\mathrm{kcal} \mathrm{m}^{-3}\right) ; \mathrm{BD}$

$=$ Basic density of the wood according to the volume of the tree $\left(\mathrm{kg} \mathrm{m}^{-3}\right)$, and GCV $=$ Gross calorific value of the wood $\left(\mathrm{kcal} \mathrm{kg}^{-1}\right)$.

\section{Data analysis}

The data obtained were subjected to statistical analysis, which proceeded with the test assumption of homogeneity of variances, analysis of variance, regression analysis, F-test, and Tukey test at $5 \%$ probability of error.

\section{RESULTS AND DISCUSSION}

Analysis of variance revealed significant effects of the three periods studied and for all tree components, on all variables analyzed. Likewise, significant effects of the four tree spacings on the biomass (BIO) and energy productivity (EP) variables were observed. When the effect of interactions between the three factors was tested, significant differences were observed for BIO, EP, Gross calorific power (GCP), fixed carbon content (FCC), and volatile material content (VMC). Significant interaction effect between year and the components was verified only for ash content (AC). Thus, we reported that there is dependence between the evaluated effects and, by doing so, the evaluation of one factor within the other was carried out.

In the $1^{\text {st }}$ year of evaluation, $\mathrm{BIO}$ and $\mathrm{EP}$ did not present significant differences between the different components of trees. For GCV and $\mathrm{AC}$, significant differences were observed, with branch and bark components presenting the highest average values. Similarly, significant differences were observed for FCC with higher average values in the wood and bark components with the smaller tree spacing. This characteristic was also observed for the VMC in the branch component (Table 1).

In the $3^{\text {rd }}$ year of evaluation, the highest values of $\mathrm{BIO}$ and $\mathrm{EP}$ were reported in the wood and branch components. For the AC, the bark had the highest average value of $4.0 \%$. As for GCV, although it was not affected by the spacing, it had the highest values in the bark component (Table 2). 
Table 1 - Average test for biomass (BIO), in ton ha ${ }^{-1}$, energy productivity (EP), in $\mathrm{Gcal} \mathrm{ha}^{-1}$, gross calorific value (GCV), in kcal $\mathrm{kg}^{-1}$, fixed carbon content (FCC), in \%, volatile material content (VMC), in \%, ash content (AC), in \%, basic density (BD), in $\mathrm{g} \mathrm{cm}^{-3}$ and energy density (ED), in Gcal m${ }^{-3}$, for the different compartments (Comp.) of Ateleia glazioviana, distributed in different planting spacing, in the $1^{\text {st }}$ year after planting.

\begin{tabular}{|c|c|c|c|c|c|}
\hline \multirow{2}{*}{ Variable } & \multirow{2}{*}{ Comp. } & \multicolumn{4}{|c|}{---Spacing (m)- } \\
\hline & & $2.0 \times 1.0$ & $2.0 \times 1.5$ & $3.0 \times 1.0$ & $3.0 \times 1.5$ \\
\hline \multirow{4}{*}{$\mathrm{BIO}$} & Wood & $0.256 \mathrm{aA}$ & $0.179 \mathrm{aA}$ & $0.165 \mathrm{aA}$ & $0.140 \mathrm{aA}$ \\
\hline & Bark & $0.044 \mathrm{aA}$ & $0.032 \mathrm{aA}$ & $0.027 \mathrm{aA}$ & $0.027 \mathrm{aA}$ \\
\hline & Branch & $0.017 \mathrm{aA}$ & $0.013 \mathrm{aA}$ & $0.010 \mathrm{aA}$ & $0.006 \mathrm{aA}$ \\
\hline & Total & $0.317 \mathrm{~A}$ & $0.224 \mathrm{~A}$ & $0.202 \mathrm{~A}$ & $0.173 \mathrm{~A}$ \\
\hline \multirow{3}{*}{ EP } & Wood & $1.172 \mathrm{aA}$ & $0.806 \mathrm{aA}$ & $0.735 \mathrm{aA}$ & $0.629 \mathrm{aA}$ \\
\hline & Bark & $0.204 \mathrm{aA}$ & $0.148 \mathrm{aA}$ & $0.122 \mathrm{aA}$ & $0.126 \mathrm{aA}$ \\
\hline & Branch & $0.078 \mathrm{aA}$ & $0.062 \mathrm{aA}$ & $0.047 \mathrm{aA}$ & $0.027 \mathrm{aA}$ \\
\hline \multirow{3}{*}{ GCV } & Wood & $4578 \mathrm{a}$ & $4502 \mathrm{~b}$ & $4455 \mathrm{~b}$ & 4492 b \\
\hline & Bark & 4626 a & $4613 \mathrm{ab}$ & $4521 \mathrm{~b}$ & $4674 \mathrm{a}$ \\
\hline & Branch & $4576 \mathrm{a}$ & 4748 a & $4704 \mathrm{a}$ & $4483 \mathrm{~b}$ \\
\hline \multirow{3}{*}{ FCC } & Wood & $20.81 \mathrm{a}$ & $19.31 \mathrm{a}$ & $17.95 \mathrm{a}$ & $18.35 \mathrm{a}$ \\
\hline & Bark & $22.29 \mathrm{a}$ & $17.45 \mathrm{a}$ & $16.50 \mathrm{a}$ & $14.92 \mathrm{~b}$ \\
\hline & Branch & $13.01 \mathrm{~b}$ & $16.02 \mathrm{a}$ & $15.72 \mathrm{a}$ & $17.11 \mathrm{ab}$ \\
\hline \multirow{3}{*}{ VMC } & Wood & $77.21 \mathrm{~b}$ & $78.90 \mathrm{a}$ & $80.38 \mathrm{a}$ & $80.09 \mathrm{a}$ \\
\hline & Bark & $74.98 \mathrm{~b}$ & $80.04 \mathrm{a}$ & $80.42 \mathrm{a}$ & $81.43 \mathrm{a}$ \\
\hline & Branch & $83.57 \mathrm{a}$ & $80.71 \mathrm{a}$ & $81.02 \mathrm{a}$ & $78.92 \mathrm{a}$ \\
\hline \multirow{3}{*}{$\mathrm{AC}$} & Wood & $1.99 \mathrm{~b}$ & $1.78 \mathrm{~b}$ & $1.67 \mathrm{~b}$ & $1.57 \mathrm{~b}$ \\
\hline & Bark & $2.74 \mathrm{ab}$ & $2.84 \mathrm{a}$ & $3.08 \mathrm{a}$ & $3.64 \mathrm{a}$ \\
\hline & Branch & $3.41 \mathrm{a}$ & $3.27 \mathrm{a}$ & $3.25 \mathrm{a}$ & $3.93 \mathrm{a}$ \\
\hline $\mathrm{BD}$ & Wood & 0.417 & 0.423 & 0.440 & 0.399 \\
\hline ED & Wood & 1.909 & 1.904 & 1.960 & 1.792 \\
\hline
\end{tabular}

Where: Means followed by lower case letters in the column do not differ between species; Means followed by uppercase letters in the line do not differ between $5 \%$ error probability spacing according to Tukey test.

For the $5^{\text {th }}$ year of evaluation, the $\mathrm{BIO}$ production and EP of the wood were significantly greater than the other components of the trees, reaching 24.712ton $\mathrm{ha}^{-1}$ and $111.797 \mathrm{Gcal} \mathrm{ha}^{-1}$, respectively. In general, for FCC and VMC, it was reported that the highest mean values were present in the wood and branch components. In contrast, for $\mathrm{AC}$, the highest value was reported for the bark. Although, not affected by tree spacing, the highest mean values of $0.519 \mathrm{~g} \mathrm{~cm}^{-3}$ and $2.347 \mathrm{Gcal} \mathrm{m}^{-3}$ were reported for basic density (BD) and energy density (ED), respectively (Table 3 ).

We observed that the four tree spacings tested led to different BIO and EP production of the three different components of the aerial parts of the trees during the three time periods after planting. A direct relationship between tree spacing and distribution of each component was observed, i.e., in the treatment with higher density $(2.0 \times 1.0 \mathrm{~m})$, the higher average values of BIO were observed when compared to the less dense spaces. According to NETO et al. (2003), there is a higher production of BIO per unit area with high tree density, mainly owing to the greater number of individuals. This justifies the decreasing trends of BIO production in the different components of the tree due to the increase in tree spacing.

However, CARON et al. (2015) pointed out that, over time, the amount of wood stored in a site tends to equalize at different spacings, and in denser plantations, there is stagnation of growth at younger ages, and that in plantings with wider spacing, the stagnation of growth appears at more advanced ages.

Figure 1 shows the significant regression equations of different components, over the three periods, for all variables evaluated. In general, there is an increasing tendency of the components, mainly wood, in the variables BIO, EP, FCC, BD, and ED, in relation to the different evaluation years, with no tendency to stabilize, because the different years 
Table 2 - Average test for biomass (BIO), in ton ha ${ }^{-1}$, energy productivity (EP), in Gcal ha ${ }^{-1}$, gross calorific value (GCV), in kcal kg ${ }^{-1}$, fixed carbon content (FCC), in \%, volatile material content (VMC), in \%, ash content (AC), in \%, basic density (BD), in $\mathrm{g} \mathrm{cm}^{-3}$ and energy density (ED), in Gcal m${ }^{-3}$, for the different compartments (Comp.) of Ateleia glazioviana, distributed in different planting spacings, in the $3^{\text {rd }}$ year after planting.

\begin{tabular}{|c|c|c|c|c|c|}
\hline \multirow{2}{*}{ Variable } & \multirow{2}{*}{ Comp. } & \multicolumn{4}{|c|}{--Spacing (m) } \\
\hline & & $2.0 \times 1.0$ & $2.0 \times 1.5$ & $3.0 \times 1.0$ & $3.0 \times 1.5$ \\
\hline \multirow{4}{*}{$\mathrm{BIO}$} & Wood & $12.656 \mathrm{aA}$ & $7.116 \mathrm{aB}$ & $6.591 \mathrm{bB}$ & $4.111 \mathrm{bC}$ \\
\hline & Bark & $1.977 \mathrm{cA}$ & $1.484 \mathrm{bB}$ & $0.939 \mathrm{cC}$ & $0.662 \mathrm{cC}$ \\
\hline & Branch & $9.543 \mathrm{bA}$ & $7.142 \mathrm{aB}$ & $7.839 \mathrm{aB}$ & $5.005 \mathrm{aC}$ \\
\hline & Total & $24.176 \mathrm{~A}$ & $15.742 \mathrm{~B}$ & $15.369 \mathrm{~B}$ & $9.778 \mathrm{C}$ \\
\hline \multirow{3}{*}{ EP } & Wood & $55.775 \mathrm{aA}$ & $31.204 \mathrm{aB}$ & $29.099 \mathrm{bB}$ & $18.064 \mathrm{bB}$ \\
\hline & Bark & $9.211 \mathrm{cA}$ & $6.751 \mathrm{bA}$ & $3.925 \mathrm{cB}$ & $2.982 \mathrm{cB}$ \\
\hline & Branch & $42.562 \mathrm{bA}$ & $31.960 \mathrm{aB}$ & $35.197 \mathrm{aB}$ & $22.317 \mathrm{aC}$ \\
\hline \multirow{3}{*}{$\mathrm{GCV}$} & Wood & $4405 \mathrm{~b}$ & $4385 \mathrm{~b}$ & $4415 \mathrm{a}$ & $4394 \mathrm{a}$ \\
\hline & Bark & 4659 a & 4549 a & $4180 \mathrm{~b}$ & $4504 \mathrm{a}$ \\
\hline & Branch & $4460 \mathrm{~b}$ & $4475 \mathrm{ab}$ & 4490 a & 4459 a \\
\hline \multirow{3}{*}{ FCC } & Wood & $17.46 \mathrm{ab}$ & $17.31 \mathrm{a}$ & $19.19 \mathrm{a}$ & $18.70 \mathrm{a}$ \\
\hline & Bark & $14.85 \mathrm{~b}$ & $19.55 \mathrm{a}$ & $18.92 \mathrm{a}$ & $14.99 \mathrm{a}$ \\
\hline & Branch & $18.42 \mathrm{a}$ & $15.94 \mathrm{a}$ & $15.44 \mathrm{~b}$ & $16.67 \mathrm{a}$ \\
\hline \multirow{3}{*}{ VMC } & Wood & $81.02 \mathrm{a}$ & $81.10 \mathrm{a}$ & $79.40 \mathrm{ab}$ & $79.62 \mathrm{a}$ \\
\hline & Bark & $81.72 \mathrm{a}$ & $76.44 \mathrm{~b}$ & $77.75 \mathrm{~b}$ & $81.05 \mathrm{a}$ \\
\hline & Branch & $79.60 \mathrm{a}$ & $81.87 \mathrm{a}$ & $82.25 \mathrm{a}$ & $81.11 \mathrm{a}$ \\
\hline \multirow{3}{*}{$\mathrm{AC}$} & Wood & $1.52 \mathrm{~b}$ & $1.59 \mathrm{~b}$ & $1.41 \mathrm{c}$ & $1.65 \mathrm{~b}$ \\
\hline & Bark & $3.43 \mathrm{a}$ & $4.00 \mathrm{a}$ & $3.34 \mathrm{a}$ & $3.96 \mathrm{a}$ \\
\hline & Branch & $1.99 \mathrm{~b}$ & $2.19 \mathrm{~b}$ & $2.30 \mathrm{~b}$ & $2.21 \mathrm{~b}$ \\
\hline BD & Wood & 0.472 & 0.468 & 0.489 & 0.486 \\
\hline ED & Wood & 2.079 & 2.052 & 2.159 & 2.135 \\
\hline
\end{tabular}

Where: Means followed by lower case letters in the column do not differ between species; Means followed by uppercase letters in the line do not differ between $5 \%$ error probability spacing according to Tukey test.

evaluated had a significant effect on the different tree components.

This difference in the distribution of BIO between different species, and for the same species, is mainly motivated by factors such as tree spacing, population age, and site quality (LADEIRA et al., 2001). This is corroborated by authors who carried out their research related to the effects of density and age of planting on the production of forest stands, such as LELES et al. (2001) and MÜLLER et al. (2005).

We observed that the age had a significant effect on $\mathrm{GCV}$, which corroborated the research done by LEMENIH \& BEKELE (2004) evaluated the effect of age on wood GCV of species of the genus Eucalyptus and observed a negative relationship with tree age, with a small difference between the ages of 11 and 21 years. VIDAURRE et al. (2012) reported similar results with Schizolobium amazonicum, reporting that the younger age presented the highest GCV values, with a tendency to decrease with increasing tree age.
The mean GCV values for A. glazioviana reported by MATTOS et al. (2000) and SILVA et al. (2012) were 4637 and $4492 \mathrm{kcal} \mathrm{kg}^{-1}$, respectively. These are lower than those described by QUIRINO et al. (2005), in which the average value of $4710 \mathrm{kcal} \mathrm{kg}^{-1}$ was observed when they carried out a literature review concerning wood GCV of 258 exotic and native tropical forest species.

Results of BD observed in this study are within the range that QUIRINO et al. (2005) reported for 108 forest species, ranging from 0.200 to $1.080 \mathrm{~g}$ $\mathrm{cm}^{-3}$. The average values of BD increased with age, with the highest values for A. glazioviana, observed in the $5^{\text {th }}$ year after planting. The differences in $\mathrm{BD}$ observed among the time periods is corroborated by a series of authors who studied this technological feature. TREVISAN et al. (2012) studied the effect of thinning on Eucalyptus grandis central trees with ages ranging from 4 to 18 years and reported a variation in the mean BD values of 0.390 to $0.462 \mathrm{~g} \mathrm{~cm}^{-3}$, confirming the existence of variability within the species and between the different ages of the stands. 
Table 3 - Average test for biomass (BIO), in ton ha ${ }^{-1}$, energy productivity (EP), in $\mathrm{Gcal} \mathrm{ha}^{-1}$, gross calorific value (GCV), in $\mathrm{kcal} \mathrm{kg}^{-1}$, fixed carbon content (FCC), in \%, volatile material content (VMC), in \%, ash content (AC), in \%, basic density (BD), in $\mathrm{g} \mathrm{cm}^{-3}$ and energy density (ED), in Gcal $\mathrm{m}^{-3}$, for the different compartments (Comp.) of Ateleia glazioviana, distributed in different planting spacings, in the $5^{\text {th }}$ year after planting.

\begin{tabular}{|c|c|c|c|c|c|}
\hline \multirow{2}{*}{ Variable } & \multirow{2}{*}{ Comp. } & \multicolumn{4}{|c|}{ 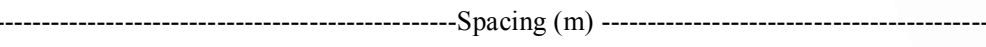 } \\
\hline & & $2.0 \times 1.0$ & $2.0 \times 1.5$ & $3.0 \times 1.0$ & $3.0 \times 1.5$ \\
\hline \multirow{4}{*}{$\mathrm{BIO}$} & Wood & $24.712 \mathrm{aA}$ & $15.498 \mathrm{aAB}$ & $22.041 \mathrm{aA}$ & $13.356 \mathrm{aAB}$ \\
\hline & Bark & $1.818 \mathrm{cA}$ & $1.148 \mathrm{cBC}$ & $1.738 \mathrm{cAB}$ & $1.017 \mathrm{cC}$ \\
\hline & Branch & $5.556 \mathrm{bA}$ & 7.242 bA & $6.585 \mathrm{bA}$ & $5.572 \mathrm{bA}$ \\
\hline & Total & $32.086 \mathrm{~A}$ & $23.888 \mathrm{AB}$ & $30.364 \mathrm{~A}$ & $19.945 \mathrm{~B}$ \\
\hline \multirow{3}{*}{ EP } & Wood & $111.797 \mathrm{aA}$ & $68.765 \mathrm{aB}$ & $99.691 \mathrm{aA}$ & $59.554 \mathrm{aB}$ \\
\hline & Bark & $8.343 \mathrm{cA}$ & $5.200 \mathrm{cAB}$ & $8.059 \mathrm{cA}$ & $4.683 \mathrm{cB}$ \\
\hline & Branch & $24.219 \mathrm{bB}$ & $32.654 \mathrm{bA}$ & $29.988 \mathrm{bAB}$ & $25.269 \mathrm{bB}$ \\
\hline \multirow{3}{*}{$\mathrm{GCV}$} & Wood & $4524 \mathrm{a}$ & $4437 \mathrm{a}$ & $4523 \mathrm{a}$ & 4459 a \\
\hline & Bark & 4589 a & $4530 \mathrm{a}$ & $4637 \mathrm{a}$ & $4605 \mathrm{a}$ \\
\hline & Branch & 4539 a & 4509 a & $4554 \mathrm{a}$ & $4535 \mathrm{a}$ \\
\hline \multirow{3}{*}{$\mathrm{FCC}$} & Wood & 20.54 a & 20.92 a & 20.94 a & $20.86 \mathrm{a}$ \\
\hline & Bark & $19.77 \mathrm{a}$ & $19.17 \mathrm{a}$ & $19.98 \mathrm{ab}$ & $20.03 \mathrm{a}$ \\
\hline & Branch & $20.97 \mathrm{a}$ & $21.61 \mathrm{a}$ & $17.33 \mathrm{~b}$ & $21.80 \mathrm{a}$ \\
\hline \multirow{3}{*}{ VMC } & Wood & $78.44 \mathrm{a}$ & $77.85 \mathrm{a}$ & $77.82 \mathrm{ab}$ & $77.96 \mathrm{a}$ \\
\hline & Bark & $76.32 \mathrm{a}$ & $76.95 \mathrm{a}$ & $76.03 \mathrm{~b}$ & $76.03 \mathrm{a}$ \\
\hline & Branch & $76.65 \mathrm{a}$ & $76.33 \mathrm{a}$ & $80.67 \mathrm{a}$ & $76.04 \mathrm{a}$ \\
\hline \multirow{3}{*}{$\mathrm{AC}$} & Wood & $1.02 \mathrm{c}$ & $1.23 \mathrm{c}$ & $1.24 \mathrm{~b}$ & $1.17 \mathrm{c}$ \\
\hline & Bark & $3.91 \mathrm{a}$ & $3.88 \mathrm{a}$ & $3.99 \mathrm{a}$ & $3.94 \mathrm{a}$ \\
\hline & Branch & $2.37 \mathrm{~b}$ & $2.07 \mathrm{~b}$ & $2.00 \mathrm{~b}$ & $2.17 \mathrm{~b}$ \\
\hline BD & Wood & 0.510 & 0.516 & 0.519 & 0.502 \\
\hline ED & Wood & 2.317 & 2.290 & 2.347 & 2.238 \\
\hline
\end{tabular}

Where: Means followed by lower case letters in the column do not differ between species; Means followed by uppercase letters in the line do not differ between $5 \%$ error probability spacing according to Tukey test.

The different tree densities did not significantly affect the BD of the wood. This result corroborated ELOY et al. (2013). These results can be attributed to several factors, such as the genetic variability of the stands and different environmental conditions, according to different ages (ELOY et al., 2014).

Our results of the VMC and FCC contents in the wood are in agreement with BRITO \& BARRICHELLO (1982). Generally, VMC ranged from $75 \%$ to $85 \%$ and FCC ranged between $15 \%$ and $25 \%$. As reported by ELOY et al. (2016b), fuels with a high FCC are desirable, because they present slower burning, implying a longer residence time within the appliances. VIEIRA et al. (2013) concluded that the VMC content positively interferes with the ignition, facilitating combustion; and although, the combustion process is rapid, it can contribute to a low energy efficiency. The same authors reported that $\mathrm{AC}$ is undesirable for an energetic product considering that it decreases the GCV, resulting in loss of efficiency because it corresponds to non-combustible substances that are in solid form.

\section{CONCLUSION}

Age affected the energy properties of the biomass of the different components of the trees. In the $5^{\text {th }}$ year after planting, the highest values of biomass, energy productivity, basic density, energy density, and fixed carbon content were obtained.

The four tree spacings $(2.0 \times 1.0 \mathrm{~m}, 2.0 \times$ $1.5 \mathrm{~m}, 3.0 \times 1.0 \mathrm{~m}$, and $3.0 \times 1.5 \mathrm{~m}$ ) provided different biomass yield and energy productivities, with a tendency to reduce their values with increasing tree spacing in all evaluated periods.

The three components of the trees (wood, bark, and branch) induced significant effects on the variables biomass, gross calorific power, energy productivity, fixed carbon content, volatile material content, and ash content.

From the energy perspective, increased age and less tree spacing resulted in better energy properties of $A$. glazioviana biomass. 

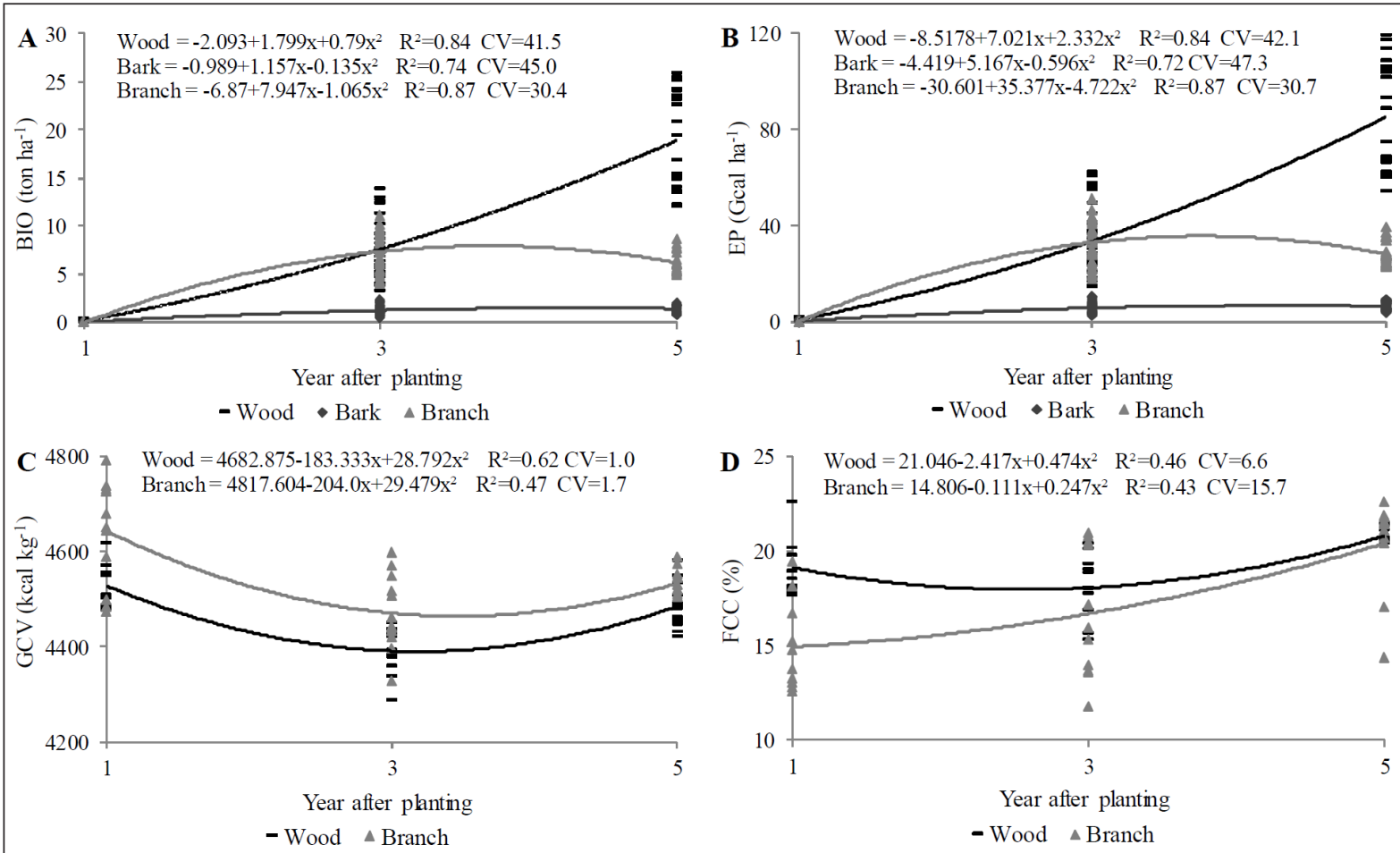

Year after planting

- Wood $\Delta$ Branch
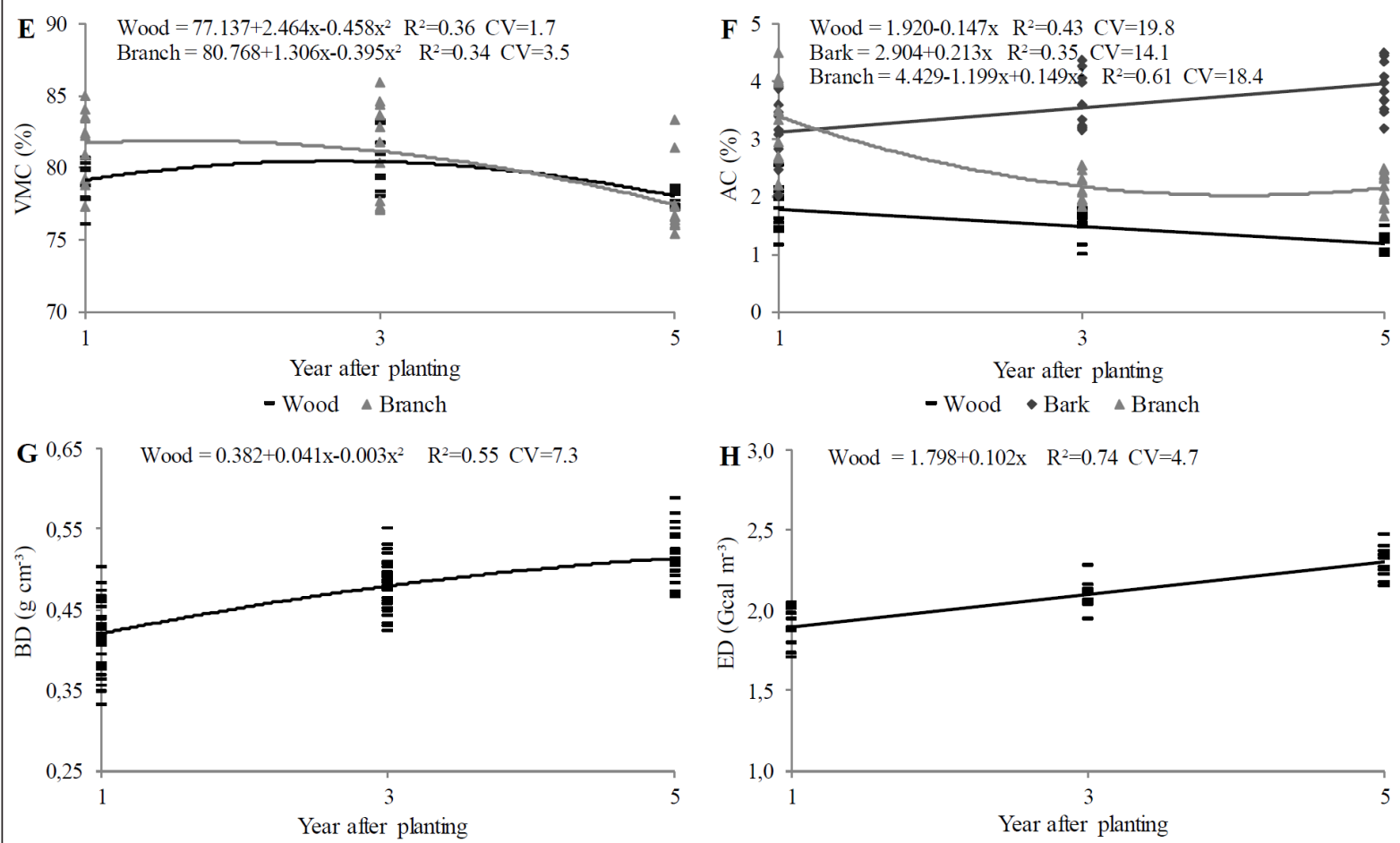

Figure 1 - Regression equations for biomass (BIO) (A), energy productivity (EP) (B), gross calorific value (GCV) (C), fixed carbon content $($ FCC) (D), volatile material content (VMC) (E), ash content (AC) (F), basic density (BD) (G) and energy density (ED) (H), in Ateleia glazioviana trees at $1^{\text {st }}, 3^{\text {rd }}$ and $5^{\text {th }}$ year after planting, distributed in different planting spacing. 


\section{ACKNOWLEDGEMENTS}

The authors acknowledge the Conselho Nacional de Desenvolvimento Científico e Tecnológico (CNPq) and the Coordenação de Aperfeiçoamento de Pessoal de Nível Superior (CAPES) for their financial support

\section{REFERENCES}

ABNT (ASSOCIAÇÃO BRASILEIRA DE NORMAS TÉCNICAS). NBR 11941: Determinação da densidade básica da madeira. Rio de Janeiro, 2003. 6p

ABNT (ASSOCIAÇ̃̃O BRASILEIRA DE NORMAS TÉCNICAS). NBR 8112: carvão vegetal: análise imediata. Rio de Janeiro, 1986. 6p.

ABNT (ASSOCIAÇÃO BRASILEIRA DE NORMAS TÉCNICAS). NBR 8633: carvão vegetal: Determinação do poder calorífico superior. Rio de Janeiro, 1984. 13p.

CARON, B.O. et al. Quantification of forest biomass in short rotation plantations with different spacings. Comunicata Scientiae, v.6, n.1, p.106-112, 2015. Available from $<$ https://comunicatascientiae.com.br/comunicata/article/ viewFile/464/309>. Accessed: Mar. 27, 2017.

ELOY, E. Produção e qualidade da biomassa de florestas energéticas no norte do Rio Grande do Sul, Brasil. 2015. 157f. Tese (Doutorado em Engenharia Florestal) - Universidade Federal do Paraná, PR.

ELOY, E. et al. Effect of planting age and spacing on energy properties of Eucalyptus grandis W. Hill ex Maiden. Revista Árvore, v.40, n.4, p.749-758, 2016a. Available from: <http:// www.scielo.br/pdf/rarv/v40n4/0100-6762-rarv-40-04-0749.pdf>. Accessed: Jun. 27, 2017. doi: 10.1590/0100-67622016000400019.

ELOY, E. et al. Influence of spacing on energy characteristics of tree species on short rotation planting. Revista Árvore, v.38, n.3, p.551-559, 2014. Available from: <http://www.scielo.br/pdf/rarv/ v38n3/v38n3a18.pdf>. Accessed: Jun. 27, 2017.

ELOY. E. et al. Energy productivity of forest species in short rotation plantings. Ciência Rural, v.45, n.8, p.1424-1431, 2015. Available from: <http://www.scielo.br/pdf/cr/v45n8/0103-8478cr-45-08-01424.pdf $>$. Accessed: Jun. 27, 2017. doi: 10.1590/0103$8478 \mathrm{cr} 20130177$.

ELOY, E. et al. Longitudinal variation and effect of spacing on basic density wood of Mimosa scabrella and Ateleia glazioveana. Floresta, v.43, n.2, p.327-334, 2013. Available from: <http:// revistas.ufpr.br/floresta/article/view/29266/20720>. Accessed: Jun. 27, 2017.

ELOY, E. et al. Effect of age and plant spacing in the energy properties of Mimosa scabrella Benth. Australian Journal of Basic and Applied Sciences, v.10, n.4, p.34-42, 2016b. Available from: <http://ajbasweb.com/old/ajbas/2016/February/34-42.pdf>. Accessed: Jun. 27, 2017.

EMBRAPA (EMPRESA BRASILEIRA DE PESQUISA AGROPECUÁRIA). Sistema brasileiro de classificação de solos. 2.ed. Rio de Janeiro: EMBRAPA-SPI, 2006. 412p.
LADEIRA, B.C. et al. Production of Eucalyptus biomass under three spacings in an age sequence. Revista Árvore, v.25, n.1, p.69-78, 2001.

LELES, P.S.S. et al. Grownth of tree species in defferent planting spacing for forest recovery. Scientia Forestalis, v.39, n.90, p.231-239, 2011. Available from: < http://www.ipef.br/ publicacoes/scientia/nr90/cap11.pdf>. Accessed: Jun. 27, 2017. doi: 10.1590/0103-8478cr20130177.

LELES, P.P.S. et al. Growth and biomass distribution in $E$. camaldulensis and $E$. pellita under different spacing in the savannah region, Brazil. Scientia Forestalis, n.59, p. 77-87, 2001. Available from: <http://www.ipef.br/publicacoes/scientia/nr59/cap06.pdf>. Accessed: Jun. 27, 2017. doi: 10.1590/0103-8478cr20130177.

LEMENIH, M.; BEKELE, T. Effect of age on calorific value and some mechanical properties of three Eucalyptus species grown in Ethiopia. Biomass e Bioenergy, v.27, p.223-232, 2004. Available from: $<$ http://www.sciencedirect.com/science/article/pii/ S0961953404000157>. Accessed: Jun. 27, 2017. doi: 10.1016/j. biombioe.2004.01.006.

LIMA, E.A. et al. Dendroenergetical characterization of Eucalyptus benthamii trees. Pesquisa Florestal Brasileira, v.31, n.65, p.9-17, 2011. Available from: <http://pfb.cnpf.embrapa.br/ pfb/index.php/pfb/article/view/192>. Accessed: Jun. 27, 2017. doi: 10.4336/2010.pfb.31.65.09.

MME (MINISTÉRIO DAS MINAS E ENERGIA). Balanço energético nacional - Ano base 2015. Rio de Janeiro: Empresa de Pesquisa, 2016. 62p.

MALUF, J.R.T. A new climatic classification for the state of Rio Grande do Sul, Brazil. Revista Brasileira de Agrometeorologia, v.8, n.1, p.141-150, 2000. Available from: <http://coral.ufsm.br/ rba/p14181.html>. Accessed: Jun. 27, 2017.

MATTOS, P.P. et al. Physical, chemical and anatomical characterization of timbo wood (Ateleia glazioviana). Colombo: Embrapa Florestas, 2000. 6p. (Comunicado Técnico, n. 47). Available from: < https://ainfo.cnptia.embrapa.br/digital/bitstream/ CNPF-2009-09/15752/1/com tec47.pdf>. Accessed: Jun. 27, 2017.

MÜLLER, M.D. et al. Biomass and energy yield evaluation of a eucalypt clone, established at different planting densities. Biomassa \& Energia, v.2, n.3, p.177-186, 2005. Available from: <http:// www.renabio.org.br/01-B\&E-012-MullerMD-2005-177-186.pdf>. Accessed: Jun. 27, 2017.

NETO, S.N.O. et al. Biomass production and distribution in Eucalyptus camaldulensis Dehn. as influenced by fertilization and spacing. Revista Árvore, v.27, n.1, p.15-23, 2003. Available from: $<$ http://www.scielo.br/pdf/rarv/v27n1/15917.pdf $>$. Accessed: Jun. $27,2017$.

PROTÁSIO, T.P. et al. Selection of Eucalyptus clones for the charcoal and bioenergy production by univariate and multivariate technique. Sientia Forestalis, v.41, n.97, p.15-28, 2013. Available from: $<$ http://www.ipef.br/publicacoes/scientia/nr97/cap02.pdf $>$. Accessed: Jun. 27, 2017

QUIRINO, W.F. et al. Calorific power of wood and ligno-cellulosic materials. Revista da Madeira, v.15, n.89, p.100-106, 2005. Available from: <http://www.mundoflorestal.com.br/arquivos/ podercalorifico.pdf>. Accessed: Jun. 27, 2017. 
SANQUETTA, C.R. Métodos de determinação de biomassa florestal. In: SANQUETTA, C.R. (Ed.). As florestas e o carbono. Curitiba: EDITORES, 2002. p.119-140.

SILVA, D.A. et al. Point of sampling along the shaft for estimate of the calorific power of the wood. Ciência Rural, v.42, n.9, p.15881595, 2012. Available from: <http://www.scielo.br/pdf/cr/v42n9/ a26412cr6161.pdf>. Accessed: Jun. 27, 2017.

TREVISAN, R. et al. Axial variation and effect of thinning on basic density of central trees of Eucalyptus grandis. Ciência Rural, Santa Maria, v.42, n.2, p.312-318, 2012. Available from: <http://www.scielo.br/pdf/cr/v42n2/a3812cr5194.pdf $>$. Accessed: Jun. 27, 2017.

VIDAURRE, G.B. et al. Energy properties of the wood and coal of paricá (Schizolobium amazonicum) tree. Revista Árvore, v.36, n.2, p.365-371, 2012. Available from: <http://www.scielo.br/pdf/ rarv/v36n2/a18v36n2.pdf $>$. Accessed: Jun. 27, 2017.

VIEIRA, A.C. et al. Characterization of rice husk for power generation. Revista Varia Scientia Agrárias, v.3, n.1, p.51-57, 2013. Available from: <http://e-revista.unioeste.br/index.php/ variascientiaagraria/article/view/6100>. Accessed: Jun. 27, 2017. 